\title{
Climate Change and Human Migration: Towards More Humane Interpretation of Refugee
}

\author{
I Gede Eka Sarjana* \\ Faculty of Law, the University of Sidney, NSW, Australia: and \\ Eco-region Development Management Center for Bali and Nusa Tenggara, \\ Ministry of Environment and Forestry of the Republic of Indonesia
}

\begin{abstract}
This article seeks to highlight the existing 1951 Convention relating to the Status of Refugees (hereinafter referred to as Refugee Convention) and the possibilities of the document to encompass climate-induced migration by modifying, reconstructing and establishing a specific legal regime, considering that the concept of Internally Displaced Persons (IDPs) has been inadequate and incapable to incorporate the 'newly introduced' type of migrant. The definition of refugee in the Convention explicitly limits the scope of people who are forced to flee their home into migrants due to warfare and civil disturbance. In fact, there are people who can no longer gain decent livelihood due to environmental and social problems including poverty, drought, soil erosion, desertification, deforestation, floods and other environmental deterioration. However, these people have not been legally accepted as 'refugee' in the international arena. The author argues that 'environmental refugee' or 'climate refugee' is a clear and present issue, as climate change-related disasters are rampant and deteriorating. Therefore, this article will examine the existing and potential role of international law in effectively responding to climate change and its related humanitarian problems in the future. The development of a specific legal document on environmental refugee and the global acceptance of the status of the people not only represent a short-term solution for the affected people, but also introduce a long-term commitment of international community to alleviate poverty and guarantee the fulfilment of basic human rights and social justice for everyone. This article primarily investigates relevant legal documents and discovers some legal and non-legal concepts that are connected to the central topic of this article.
\end{abstract}

Keywords: Climate Change; Refugee; Displacement; Migration.

How to Cite (chicago-16th): Sarjana, I Gede Eka. "Climate Change and Human Migration: Towards More Humane Interpretation of Refugee." Udayana Journal of Law and Culture 2, no. 2 (2018): 220-248. https:// doi.org/110.24843/UJLC.2018.v02.i02.p05

DOI: https:/ / doi.org/ 10.24843/UJLC.2018.v02.i02.p05

\section{Introduction}

\subsection{Background}

Despite the controversies surrounding the uncertain scientific aspects of climate change in the political arena, climate change and its adverse effects are likely to have appalling consequences for human life if humans do not make significant efforts to deal with this global phenomenon. Not surprisingly, a variety of catastrophic events such as tropical storm surges, sea level rise, biodiversity loss, floods and droughts are bearing down upon us.

E-mail/Corresponding Author: ekasarjana12@gmail.com 
The international community has witnessed the horrendous and widespread impacts of climate change, both on the environment and on humans. ${ }^{1}$ However, global concern has, to date, focused on how to mitigate and prevent further devastating impacts, with less concern about the people who are seriously affected by these calamities. People have lost their homes, properties and families due to enormous typhoons in many countries. They have lost their access to food and clean water due to extreme weather. ${ }^{2}$

However, it is highly challenging to establish scientific evidence that climate change is the trigger of, and is strongly manipulating, the decision of people to migrate. This is due to the fact that the roles of contributing factors, such as economic hardship, political strife, poverty, unemployment and armed conflict are mingled and difficult to disentangle. ${ }^{3}$ Consequently, environmental factors cannot be clearly identified and isolated from the others. ${ }^{4}$

Human displacement or migration is not a new phenomenon in human history. ${ }^{5}$ People move from one place to the other due to a wide variety of reasons, including natural and environmental disasters. The history of human movement caused by natural disasters, such as volcanic eruptions and earthquakes, for example, started hundreds of years ago as a common effort to survive disaster. ${ }^{6}$ Regardless the legal definition stipulated in the Refugee Convention, practically, the movement can be

1 See Ben Boer and Alan Boyle, "Human Rights and the Environment." Background Paper for the 13th Informal ASEM Seminar on Human Rights, Sydney Law School Research Paper, no. 14/14. (2014): 1-88. http://dx.doi.org/10.2139/ssrn.2393753; See also United Nations Environment Programme, 'Climate Change and Human Rights. Report (2015): 1-10; Michael Brzoska and Christiane Fröhlich, "Climate Change, Migration and Violent Conflict: Vulnerabilities, Pathways and Adaptation Strategies," Migration and Development 5, no.2 (2016): 190-210. https://doi.org/10.1080/21632324.2015.1022973; also the discussion on 'Climate Change and Atmospheric Pollution' in Patricia Birne, Alan Boyle, Catherine Ridgwell, 'International Law and the Environment, (New York: Oxford University Press, 2009): 335-378; also Walter Kalin, 'The Climate Change-Displacement Nexus', (Brookings, 2008); <http://www.brookings.edu/ research/speeches/2008/07/16-climate-change-kalin>

2 See UNHCR, 'UNHCR Backs Increased Protection for People Fleeing Disasters and Climate Change' (2015)<http://www.unhcr.org/news/latest/2015/10/561e77f56/unhcr-backs-increased-protection-people-fleeing-disasters-climate-change.html>

3 See the discussion on 'Conceptualizing Climate Change-Related Movement' in Jane McAdam, Climate Change, Forced Migration, and International Law (New York: Oxford University Press, 2012); see also Vikram Kolmannskog and Lisetta Trebbi, "Climate Change, Natural Disasters and Displacement: A MultiTrack Approach to Filling the Protection Gaps." International Review of the Red Cross 92, no. 879 (2010): 713-730. https://doi.org/10.1017/S1816383110000500

4 Jane McAdam, "Swimming against the Tide: Why a Climate Change Displacement Treaty is not the Answer," International Journal of Refugee Law 23, no. 1 (2011): 13-14.

5 Vikram Odedra Kolmansskog, 'Future Floods of Refugees: A Comment on Climate Change, Conclict and Forced Migration', (2008) Norwegian Refugee Council<http:/ /www.migrationdrc.org/publications / resource_guides/Migration_and_Climate_Change/Future_floods_of_refugees.pdf>

6 Alberto Angulo Morales, Oscar Alvarez Gila, 'Disasters and Migration in Western Early Modern Societies (17th-18th Centuries)', (2014) Migracionesen 3 Milenio.indd<http://www.academia.edu/6717913/ Disasters_and_Migration_in_Western_Early_Modern_Societies_17th-18th_Centuries>; see also: Carolina Fritz, 'Climate Change and Migration: Sorting Through Complex Issues Without the Hype', (2010)<http:// www.migrationpolicy.org/article/climate-change-and-migration-sorting-through-complex-issues-withouthype> 
within a national territory, in which case people are known as internally displaced persons' (hereinafter referred to as IDPs), or beyond national borders, where they are considered 'migrants' or 'refugees'. According to the United Nations High Commissioner for Refugees (hereinafter referred to as UNHCR), natural and man-made disasters have forced millions of people to relocate every year since $2008 .{ }^{7}$ The International Organization of Migration has made a similar prediction: that within a few more decades approximately 200 million people will have to flee their home due to environmental matters. ${ }^{8}$

In the environmental context, a variety of terms have been used to define people who migrate to other countries due to unliveable environmental conditions. ${ }^{9}$ One term frequently used in the media or informally accepted among international community is 'environmental refugees' or 'climate refugees'. This term is used to clarify the link between the adverse effects of climate change and human displacement. ${ }^{10}$ Regardless of the ongoing controversy on the terminology, in this article, the term 'climate refugees' 11 is used to refer to those who are forced to leave their home as a result of environmental degradation, within and outside their country.

Considering several cases on the application to seek environmental refugee status, this article argues that the existing approaches to and views on 'climate refugees' or 'environmental refugees' ${ }^{12}$ have been too narrow and unfair, compared to the views on the Refugee Convention. Moreover, the existing Refugee Convention has been, to some extent, disadvantageous and rigid, causing serious impediment in its implementation to the current development of human displacement.

7 UNHCR, 'UNHCR Pledges to Better Protect and Assist People Displaced by Disaster' (2016)<http: / / www.unhcr.org/news/latest/2016/5/574843f34/unhcr-pledges-better-protect-assist-people-displaceddisaster.html>

8 International Organization for Migration, 'Migration, Environment and Climate Change: Assessing the Evidence', (2009)<http://publications.iom.int/system/files/pdf/migration_and_environment.pdf>

9 Olivia Dun and Francois Gemenne, "Defining 'Environmental Migration," Forced Migration Review 31 (2008): 10-11. http:/ / ro.uow.edu.au/cgi/viewcontent.cgi?article=2406\&context=sspapers

10 See Antonio Guterres, 'Climate change, natural disasters and human displacement: a UNHCR perspective', (2008) <http://www.unhcr.org/4901e81a4.pdf>

11 The term has long been used and accepted by scholars in many international journals and documents. For example, see Richard Black, "Environmental Refugees: Myth or Reality?", UNHCR Working Papers 34 (2001); see also Norman Myers, "Environmental Refugees in a Globally Warmed World," Bio Science 43, no. 11 (1993): 752-761. DOI: 10.2307/1312319; see also Norman Myers, "Environmental Refugees: An Emergent Security Issue", A paper presented at the Economic Forum (May 2005) https://www.osce.org/ eea/14851?download=true ; see also Essam El Hinnawi, "Environmental Refugees", UNEP (1985); see also David Keane, "The Environmental Causes and consequences of Migration: A Search for the Meaning of 'Environmental Refugees'," Georgetown International Environmental Law Review 16 (2004).

12 Although the use of the term 'climate/environmental refugees' has been considered a legal mistake by some scholars, because it is not in accordance with the definition of refugee set out in the 1951 Refugee Convention, for the purpose of this article, the terms 'environmental migrants', 'climate refugees', or 'environmental refugees' will be used interchangeably to classify people who should and would potentially leave their place of origins due to the insistence of the environment, especially climate change. 
Although climate change has been considered as one of the biggest environmental problems of humankind, not many progresses were achieved over the last few decades on the status of the people affected by this global catastrophe. Only a few scholars and international human rights bodies advocate the newly introduced term, 'Environmental refugees' or 'climate refugee' to be accepted in the international legal document. The term was introduced by Essam El-Hinnawi (UNEP) in 1985, followed by other scholars including Norman Myers ${ }^{13}$, Diane C. Bates ${ }^{14}$, Elizabeth Burleson $^{15}$, Richard Black ${ }^{16}$ and others.

\subsection{Purpose}

This article explores the possibilities of climate-induced migrants to be considered as refugees under the international legal regime. It discusses the development of a more flexible human rights legal regime to encompass a wider range of displacement. In doing so, this paper examines the existing Refugee Convention in dealing with human displacement to determine whether the Convention encompasses a wide range of human displacement.

This article does not attempt to look at the fallacies and the weaknesses of the existing Refugee Convention, nor does it challenge the psychological and historical background behind the development of the document. Rather, it aims to find an adequate space between the legal normative instrument and the reality, where decision makers could consider the necessity of being innovative in interpreting the law to prevent a legal vacum for the sake of humanity. In other words, dynamic interpretation of the existing instruments should be implemented to provide protection for the affected people, including the implementation of relevant international legal principles to ensure that the rights of the affected people are fully protected.

\subsection{Method}

This writing reflects a legal research that primarily investigates relevant legal documents and discovers some legal and non-legal concepts that are connected to the central topic of this article. The analysis is established by contending legal principles and norms as stipulated in international legal instruments as well as facts, concepts, and theories as provided in reports, textbooks, scientific journal and reviews. In particular, provisions contained in some legal instruments are interpreted beyond the creator's intention but are construed in a dynamic means by taking into consideration the current context and the development of international community's common sense.

13 Norman Myers, 'Environmental Refugees," Population and Environment 19, no.2 (1997): 167-182. https://doi.org/10.1023/A:1024623431924

14 Diane C. Bates, "Environmental Refugees? Classifying Human Migrations Caused by Environmental Change," Population and Environment 23, no. 5 (2002): 465-477.

15 Elizabeth Burleson, 'Climate Change Displacement to Refuge,' Journal of Environmental Law and Litigation 25, no. 19 (2010): 19-36.

16 Richard Black, Op.Cit. 
This article will proceed in the following order: (1) describing the introductory part that comprises background, purpose, method, and literature review; (2) explaining the result of research inquiries and the analysis. This section starts with an intertwining relationship between climate change and human movement. It also discusses various interpretation to classify environmental migrants as refugee by scrutinizing the meaning of persecution stipulated in the Convention as well as incorporating humanitarian aspects.

Lastly, this article deconstructs the formulation of 'refugee' in order to highlight the link between climate changes and human migration. To do so, the perspectives from both developed and developing countries are compared in establishing an argument that strongly supports environmental migrants to obtain equal protection as currently enjoyed by traditional refugees. This article is concluded by reiterating and emphasizing that, although environmental refugees or climate refugees are not legally comprehended in the international legal framework, it is morally wrong for states and international organisations to leave them behind for a problem they did little or nothing to cause.

\subsection{Literature Review}

It has been widely acknowledged that the issue of refugees has received major attention all over the globe. ${ }^{17}$ Some studies were carried out to monitor the progress of international soft law on refugees. As an example, Hansen reviews the progress of the Comprehensive Refugee Response Framework (CRRF), ${ }^{18}$ a framework that is based on the United Nations General Assembly Resolution, to be developed and initiated by UNHCR for any situation involving large movements of refugees. ${ }^{19}$ Another instance is the recent outlook on the establishment of a Global Compact on Refugees, ${ }^{20}$ a non legally binding document that based on the New York Declaration and builds upon CRRF for predictable and equitable burden and responsibility sharing among UN members. ${ }^{21}$

Dallal Stevens discusses the implications of state sovereignty over a generous, meaningful and humane approach to asylum by taking a look at the recent situation

17 See for example how media may play a vital role in determining public opinion on refugees crisis in Esther Greussing and Hajo G. Boomgaarden, "Shifting the Refugee Narrative? An Automated Frame Analysis of Europe's 2015 Refugee Crisis," Journal of Ethnic and Migration Studies 43, No. 11 (2017): 1762-1764, http:/ /dx.doi.org/10.1080/1369183X.2017.1282813

18 Randall Hansen, “The Comprehensive Refugee Response Framework: A Commentary,” Journal of Refugee Studies 31, no. 2(2018): 131, doi:10.1093/jrs/fey020

19 Resolution, United Nations General Assembly, A/RES/71/1 (2016), Annex I, para 2.

20 Meltem Ineli-Ciger, "Will the Global Compact on Refugees Address the Gap in International Refugee Law Concerning Burden Sharing?” European Journal of International Law (2018), https://www.ejiltalk. org/will-the-global-compact-on-refugees-address-the-gap-in-international-refugee-law-concerning-burden-sharing/

21 The Global Compact on Refugees, the Final Draft (as at 26 June 2018), para 4. http:/ /www.unhcr.org/5b3295167 
of Syrian migration to European countries. ${ }^{22}$ It provides an approach that resulted in a view that the European Union has not fully harmonized asylum policy in order to establish minimum acceptable standards for applicants and ensure the granting of international protection to beneficiaries. ${ }^{23}$ The study found that membership of, and integration into, a new community, is the meaning of asylum and protection for the refugee. ${ }^{24}$

Worster conducted a study to discuss the use of human-centered interests in expanding the legal concept of refugees as defined in the Convention under customary international law and the use of state-centered interests in narrowing such definition. ${ }^{25}$ It suggested that defining refugee under customary international law should include inter alia individuals persecuted on the basis of gender or sexual orientation. ${ }^{26}$ Another study from Jenny Poon recommends to expand the definition of "persecution" by recognising environmental refugees as members of "a particular social group", or creating an entirely new treaty. ${ }^{27}$

Scholars have been discussing the existing formulation of 'refugee' and 'the crisis' over the last few decades. ${ }^{28}$ John R. Wennersten and Denise Robbins highlight the catastrophic impact of climate change on human displacement in many countries, specifically in Asia and Africa. The authors argue that millions of people have been hit by climate-related calamities and compelled to flee their homes as refugee, while the term 'environmental refugees' has not been legally accepted. ${ }^{29} \mathrm{~A}$ more interesting and contradicting opinion comes from Rebecca Hingley. While other scholars promote the term 'environmental refugees' to be internationally accepted, Hingley demands international community to help the affected people to solve their problem. The setting of Her argument was in the Pacific region, which consists of many low-lying island states such as Tuvalu, Samoa, Tonga, Maldives and Kiribati. She argues that the consistent use of the term 'environmental refugees' will only create a negative image such as weak and hopeless to the affected people instead of strong and brave. She also underlines actors in which the term 'environmental

22 Dallal Stevens, "Asylum, Refugee Protection and the European Response to Syrian Migration," Journal of Human Rights Practice 9 (2017): 184, doi: 10.1093/jhuman/hux016

23 Ibid, 186.

24 Ibid, 185.

25 William Thomas Worster, "The Evolving Definition of the Refugee in Contemporary International Law", Berkeley Journal of International Law 30, no. 1 (2012): 94. http://dx.doi.org/https://doi. org/10.15779/Z38ZP90

26 Ibid, 158. On the issue of persecution, see Section 2.3 of the present article.

27 Jenny Poon, "Addressing the Protection Gap of Environmental Refugees: A Reform of the 1951 Refugee Convention?," GroningenJournal of International Law, (March2017), https:/ / grojil.org/2017/03/28/ addressing-the-protection-gap-of-environmental-refugees-a-reform-of-the-1951-refugee-convention/

28 Cigdem Bozdag And Kevin Smets, "Understanding the Images of Alan Kurdi With 'Small Data': A Qualitative, Comparative Analysis of Tweets About Refugees in Turkey and Flanders (Belgium)" International Journal of Communication 11 (2017): 4064.

29 John R. Wennersten and Denise Robbins, Rising Tides: Climate Refugees in the Twenty-First Century, (Indiana University Press 2017). 
refugee' is consistently promoted and elevated. However, she urges actions from developed countries to assist the affected people by reducing their emission instead of labelling them with 'environmental refugees'. ${ }^{30}$

Bayes Ahmad offered critical overview of accommodating the climate refugees by countries and proposed an innovative method by considering the status of climate pollution, resource consumption, economy and human development rankings to address the problem by bringing humanitarian justice to the ultimate climate refugees. ${ }^{31}$ In addition, Wennersten et.al acknowledges that the concept of climate refugees is a legitimate category without any convincing justification. ${ }^{32}$

\section{Result and Analysis}

\subsection{Climate Change and Human Movement: A Matter of Causalities}

While the scientific aspects of climate change have become the most common topics of discussion among scholars and the scientific community, the social and humanitarian aspects of this global phenomenon have received little attention. ${ }^{33}$ Although human displacement has been considered one of the most severe social impacts of climate change, ${ }^{34}$ the impact on transboundary human displacement is considered a less appealing issue, and therefore, has not been legally stipulated in international instruments.

In the latest synthesis reports, the Intergovernmental Panel on Climate Change (IPCC) has suggested that the adverse impacts of climate change will potentially affect humans in various ways, including human movement, and has suggested that human displacement is one of the most effective adaptation mechanisms ${ }^{35}$ Scholars and international humanitarian agencies have projected that the number of people who have to migrate as a result of climate change will continue to grow within the

30 Rebecca Hingley, "Climate Refugees: An Oceanic Perspective," Asia and the Pacific Policy Studies 4 , no. 1 (2017): 158-165.

31 Bayes Ahmed, "Who TakesResponsibility for the ClimateRefugees?," International Journal of Climate Change Strategies and Management 10, no 1 (2018), https://doi.org/ 10.1108/ IJCCSM-10-20160149 (2018): 5.

32 Andrew Baldwin, "Rising Tides: Climate Refugees in the Twenty-first Century," by Wennersten, John, and Robbins, Denise. book review, International Migration Review 1-3 , 2018.

33 Antonio Guterres, Op.Cit.

34 IPCC, 'Climate Change 2007: Impacts, Adaptation and Vulnerability' (2007)<https://www.ipcc. $\mathrm{ch} /$ pdf/assessment-report/ar4/wg2/ar4_wg2_full_report.pdf $>$; While it is also considered by the IPCC as a normal adaptation measure against climate change

35 IPCC, 'Climate Change 2014: Synthesis Report', (2015), 73 <http://www.ipcc.ch/pdf/assessment-report/ar5/syr/SYR_AR5_FINAL_full.pdf>; Although for one island state in the pacific, human displacement is not supposed to be part of adaptation mechanism in international instrument, because it would give an impression that the complexity of climate change can be easily solved by displacing people, instead of reducing the greenhouse gases emission which have been identified and accepted as the major cause of the phenomenon. 
next two or three decades. ${ }^{36}$ However, does this mean that climate change will necessarily trigger human displacement?

The issue of whether or not environmental degradation, or specifically climate change, is the cause of human displacement has become a highly controversial topic among international scholars over the last two decades. ${ }^{37}$ While more physical evidence on this matter has been provided by the influx of people affected by environmental degradation, ${ }^{38}$ the link to climate change is not straightforward. There have been misconceived or misguided opinions that the adverse effects of climate change, such as droughts and sea level rise, have become an immediate force that have driven the affected people to flee their homes. Although there is a close relationship between environmental degradation and climate change, climate change is not necessarily the root cause of environmental degradation that leads to human displacement. ${ }^{39}$ Various other problems that already exist in particular regions, such as over-population, unemployment, poverty, inequality of resources, political instability, lack of education and health problems, may play major roles in triggering human migration.

Numerous international scholars have asserted that extreme events as a result of climate change such as floods, droughts, tropical storm and sea level rise are important factors that aggravate these pre-existing conditions. ${ }^{40}$ In other words, affected communities, or communities with less ability to cope with the existing conditions are highly vulnerable to environmental changes, especially global warming or climate change-related calamities.

Such events are also indirectly associated with civil strife and armed conflicts in various countries, especially in less developed countries with limited natural resources. ${ }^{41}$ Droughts and floods in certain parts of Africa and Asia as a result of increased temperature and extreme weather have led to a significant decline in food production. As a result, famine and competition for basic needs and natural resources amongst community members has increased, which in turn has, in most cases, led to prolonged civil conflicts ${ }^{42}$

36 Norman Myers, 'Environmental refugees: A Growing Phenomenon of the 2st Century' (2001) The Royal Society 609<http://rstb.royalsocietypublishing.org/content/royptb/357/1420/609.full.pdf>; see also: UNHCR, '2007 Global trends: Refugees, Asylum Seekers, Returnees, Internally Displaced and Stateless Persons' (2008) <http:/ /www.unhcr.org/4852366f2.html>

37 Richard Black, Op.Cit.

38 Myers, Op.Cit.

39 Richard Black, Op.Cit.

40 See Jane Mc Adam, Op.Cit; See also: Steve Lonergan, "The Role of Environmental Degradation in Population Displacement," Environmental Change And Security Project Report 4, no. 6 (1998): 5-15.; see also Gaim Kibreab, "Environmental Causes and Impact of Refugee Movements: A Critique of the Current Debate," Disasters 21, no. 1 (1997): 20-38. https://doi.org/10.1111/1467-7717.00042

41 Vikram Kolmannskog and Lisetta Trebbi, Op.Cit.

42 This situation has forced the UN to issue such Resolution, for example the UNSC Resolution 1376 (2001) regarding Ceasefire Agreement in Congo; and also the UNSC Resolution 1478 (2003) with regard to conflict in Liberia; See also Cullen S. Hendrix and Idean Salehyan, "Climate Change, Rainfall, and Social Conflict in Africa," Journal of Peace Research 49, no. 1 (2012): 35-50. https://doi.org/10.1177/0022343311426165 
The armed conflict that occurred in Darfur, Sudan, regardless of other pre-existing stressors, can be considered as one example of a conflict that was ignited by one of the climate change-related disasters, drought. ${ }^{43}$ The Sudanese government claimed that water scarcity, which led to a drastic decline in food production, triggered a prolonged traditional conflict among community members. ${ }^{44}$ However, it is simplistic to say that climate change will lead to civil strife or armed conflict. Therefore, further research is needed to show the intertwined between the two and examine the role of other factors.

While the connection between climate change and human displacement has gained international recognition from the majority of scholars and academics, using climate change as the legal basis to seek international protection or specifically refugee status is problematic. The complexity is obvious from the few cases brought before Australian and New Zealand courts by those who have been severely affected by climate change. In those cases, the courts have refused to grant international protection status to the applicants because the claims are not in accordance with the definition of refugee stipulated in the existing 1951 Refugee Convention. ${ }^{45}$

In making their decisions, the courts considered several factors in order to establish a causal link between climate change and the application of refugee status. The courts took into consideration the existing definition in the Convention and related national legislation of the country, where the application is submitted. Firstly, the cause of the migration must be determined: whether or not the environmental pressures is the only reason underlying the applicant's decision to migrate. This point requires solid scientific evidence, and obtaining a definitive answer takes a long time, given the contribution of other pre-existing economic factors such as poverty, unemployment, and so on. Secondly, the size or the extent of environmental changes or environmental stress that induced the migration must be determined. It is difficult for the decision makers to decide whether or not a particular event is severe enough to force the affected communities to flee their home. Thirdly, the court must determine whether the time span of the environmental stress is sufficient to force the affected people to migrate. Given that such events can have a long-term impact, or can cause damage after a certain period of time, it is necessary to conduct a thorough scientific analysis to predict the timing and duration of the environmental impact.

43 For more information, see World Food Program USA Report, "Winning the Peace: Hunger and Instability" (December 2017); see also: Chase Sova, "The First Climate Change Conflict", World Food Program USA (November 2017) https://wfpusa.org/articles/the-first-climate-change-conflict/

44 Jan Selby and Clemens Hoffmann, "Beyond Scarcity: Rethinking Water, Climate Change and Conflict in the Sudans," Global Environmental Change 29 (2014): 360-370. https://doi.org/10.1016/j. gloenvcha.2014.01.008; Watch also a video from Al Jazeera, 'Inside Story: Is Climate Change A Global Security Threat?', (2011);<https:/ /www.youtube.com/watch?v=7KsegrvRWZQ>

45 N95/09386 [1996] RRTA 3191 (7 November 1996); 0907346 [2009] RRTA 1168 (10 December 2009); 1004726 [2010] RRTA 845 (30 September 2010). See also: Immigration and Protection Tribunal New Zealand, "[2014] NZIPT 800517-520 <https://forms.justice.govt.nz/search/IPT/Documents/Deportation/ pdf/rem_20140604_501370.pdf> 
Although one prominent case, a Kiribati man's application for environmental refugee status in New Zealand has come to distressing ending in 2015, it has, at least, put an outset for the newly-introduced migration to be considered as a refugee in the future. The current situation seems to turn around from 'zero to hero' when New Zealand Prime Minister has given a sign that New Zealand government will open serious discussion with Pacific Nations over the creation of special refugee visa mechanism for Pacific Island residents who are forced to flee their country due to climate-related disasters. ${ }^{46}$

\subsection{Are Environmental Migrants Considered Refugees?}

To determine whether or not a group of people who are displaced from their original home can be defined as refugees, it is important to understand the definition of refugee based on the existing international law.

Article 1(A)(2) of the 1951 Convention Relating to the Status of Refugee ${ }^{47}$ (hereinafter referred to as Refugee Convention) defines a refugee as: "Someone who owing to well-founded fear of being persecuted for reasons of race, religion, nationality, membership of a particular social group or political opinion, is outside the country of his nationality and is unable or, owing to such fear, is unwilling to avail himself of the protection of that country".

This definition demonstrates the narrow and stringent scope of the Convention. In order to be defined as a refugee, a person needs to satisfy four main criteria:

1. Have an obvious fear or be under threat, or potential threat of persecution;

2. The persecution is on the grounds of race, nationality, religion, membership of particular social group, or political opinion;

3. Be outside of his/her home country;

4. Unable or Unwilling to avail himself of the protection.

These four important points set out in the 1951 Refugee Convention become highly debatable when determining whether or not people migrating due to environmental stress can be categorized as refugees.

A wider interpretation of the term refugee can be seen in regional human rights documents, such as the African Union Convention, ${ }^{48}$ which describes refugees as:

46 See Jonathan Pearlman, "New Zealand Creates Special Refugee Visa for Pacific Islanders Affected by Climate Change", the Straits Times (December 2017). https://www.straitstimes.com/asia/australianz/ new-zealand-creates-special-refugee-visa-for-pacific-islanders-affected-by-climate

47 Convention relating to the status of Refugee, adopted 28 July 1951, entered into force 22 April 1954.

48 NAfrican Union Convention, <http://www.achpr.org/files/instruments/refugee-convention/achpr_instr_conv_refug_eng.pdf> 
...every person who, owing to external aggression, occupation, foreign domination or events seriously disturbing public order in either part or the whole of his country of origin or nationality, is compelled to leave his place of habitual residence in order to seek refuge in another place outside his country of origin or nationality.

This wide interpretation should become a model for other regions to deal with international humanitarian problems.

Human displacement is considered to be one of the greatest impacts of climate change. ${ }^{49}$ Within the last decade, millions of people have been uprooted from their initial home as a result of climate change as they attempt to find better places within or beyond their national territories. ${ }^{50}$ Millions more will potentially move in the future, according to projections made by international environmental and humanitarian bodies including UNHCR and IPCC, as countries continue to release greenhouse gases into the atmosphere. ${ }^{51}$

Various terms are used to describe people who leave their homes due to environmental change, ${ }^{52}$ including 'environmental migrants', 'environmental refugees', 'climate refugees', and 'ecological migrants'. However, until recently there has been no legally acceptable consensus among scholars and international bodies regarding an appropriate term for this group of people.

The International Organization for Migration (IOM) has defined Environmental migrants as follows:

...persons or groups of persons who, for reasons of sudden or progressive changes in the environment that adversely affect their lives or living conditions, are obliged to have to leave their habitual homes, or choose to do so, either temporarily or permanently, and who move either within their territory or abroad. ${ }^{53}$

Although defining environmentally-induced displacement seems to be the best and the most appropriate attempt to provide stronger protection and legal status for the group, ${ }^{54}$ the situation of an environmental refugee does not clearly fit into the definition of refugee as stipulated in the Refugee Convention. Therefore, extending

49 IPCC, Op. Cit.

50 See press release by the United Nations University, As Ranks of "Environmental Refugees" Swell Worldwide, Calls Grow for Better Definition, Recognition, Support, (October 2005);<http://www.ehs.unu. edu/file/get/3916>

51 Freija Van Duijne, 'Scientists's Prediction of Climate Change: Business as Usual Versus Alternative Futures', (2015); <http://futuristablog.com/scientists-prediction-climate-change-business-usualversus-alternative-futures / $>$

52 Olivia Dun and Francois Gemenne, Op.Cit.

53 IOM, 'Migration, Climate Change and the Environment', <https://www.iom.int/cms/en/sites/ iom/home/what-we-do/migration-and-climate-change/definitional-issues.html>

54 Olivia Dun and Francois Gemenne, Op.Cit. 
the definition of refugee set out in the Refugee Convention to include other types of migrants, or creating a new treaty or protocol of the existing convention, is considered urgent by many scholars, ${ }^{55}$ although it may not be an appropriate alternative given the risk of weakening the legal consequences of protection that had been given to the 'convention refugees'. ${ }^{56}$

In the context of the responsibility of the state, there are several issues to be raised, especially at the time the affected people are forced to flee their homes, these include: the responsibility or willingness of the states to assist the affected people to cross their national border; the ability of the affected communities to gain access to other countries and to convince them to render their assistance; and the power of international humanitarian agencies to encourage other countries to assist the affected community to seek refuge, and at the same time, to protect them when they are outside of their national territory.

In order to respond to those issues, strong commitment from the states and the support of international bodies, mainly the United Nations, are essential.

\subsection{Converging the Possibilities}

As described previously, the most widely accepted definition of 'refugee' comes from the Refugee Convention. The first part of the Convention definition is persecution. This term is closely associated with an act conducted intentionally by humans and/ or the power of one group over others. From a historical point of view, the state of war and conflicts in many countries during the Second World War was the background and the foundation of the establishment of the Convention in 1951. Therefore, the protection of people in countries where conflict and physical violence is still a frightening spectre has formed the content and formulation of the document. However, this does not mean that the term persecution should be construed and interpreted in a rigid way, especially for the sake of humanity. Moreover, this international document is supposed to be dynamic and open to development.

In general, the term persecution can be defined as pressure and repression carried out by the ruling government over a person or group of people in order to stop activities that, from the government's standpoint, will potentially lead to horizontal conflict, social unrest or threaten the government position.

The definition of persecution should not be seen narrowly in terms of the actors

55 Biermann and I. Boas, 'Preparing for a Warmer World: Towards a Global Governance System to Protect Climate Refugees', (2007) 33 Global Governance Working Paper; see also Angela Williams, "Turning the Tide: Recognizing Climate Change Refugees In International Law," Law \& Policy 30, no. 4 (2008): 502-529. https://doi.org/10.1111/j.1467-9930.2008.00290.x; also Bonnie Docherty and Tyler Giannini, 'Confronting a Rising Tide: A Proposal for a Convention on Climate Change Refugees', (2009), 33 Harvard Environmental Law Review, 349-350; see also a draft Convention on the International Status of Environmentally-Displaced Persons, (2013) <http://intergenlaw.com/wp-content/uploads/2015/02/ Draft-Convention-on-the-International-Status-on-environmentally-displaced-persons-third-version.pdf $>$ 56 UNHCR, Op.Cit. 
who perform the acts of persecution. It should be seen as a complex process, including the consequences caused by the actions of the person or group of people and the ability of the government to protect its citizens. Persecution should be seen as an act that brings negative consequences for people who experience it. When persecution is narrowly defined based on the actors, it will be understood differently. Some actions that are not illegal in one country may be considered as persecution by outsiders. For example, when a legitimate government attempts to implement what is stipulated in domestic law in order to punish a person or group of people who commit acts of treason against the government. Another example is when a government tries to fight a group of rebels from a particular race or religion, which has obviously created public insecurity and fear in the community.

The major elements of persecution should emphasize the external stresses, fears, and potential threats, experienced by the affected communities, without the element of crime. Therefore, environmental factors that cause unpleasant conditions and stress may be considered a persecution, regardless of the actors who cause such conditions.

The ability of the government to protect its citizens and to ensure the fulfillment of their basic rights should also be a consideration for decision makers in determining the elements of persecution. The willingness and the ability of the government could be two different issues. In certain cases, the government is willing to guarantee and protect the rights of its citizens, but in fact is unable to do so. When the government is unable to protect its citizens due to economic constraints, the question remains as to whether it can be considered persecution.

In a few cases regarding the application for environmental refugee status in Australia and New Zealand, the interpretation of the term 'persecution' became one key element of the court's decision. The court/tribunal refused to grant refugee status to the applicants due to the 'indiscriminate effect' of climate change. The court argued that the impacts of climate change, which formed the legal basis of the claim were not deliberately aimed at certain individuals or particular groups of people in Tuvalu and Kiribati. They argued that climate change happens to everyone in those countries or even in the world without exception. ${ }^{57}$ This argument seems shallow and ignored the fact that the applicants were actually experiencing an unbearable situation in their home countries. At the same time, the decision overlooked the extent of damage and the level of difficulty encountered. The reasoning that the impact of climate change affects all people in both countries is not firm enough and generalized the situation. In fact, not all people who were living in these countries experienced the same situation, feeling, fear and threat. People who lived further away from the shore or on the higher ground did not experience the same problem faced by the applicants.

57 The Telegraph, 'Kiribati Climate Change Refugee Rejected by New Zealand', (2013); <http://www. telegraph.co.uk/news/worldnews/australiaandthepacific/kiribati/10474602/Kiribati-climate-changerefugee-rejected-by-New-Zealand.html 
From the victim's standpoint, climate change does not, in fact, have the same effect on everyone in a particular region. An increase in temperature of 1 degree Celsius, for example, would be perceived as a bearable by those who live in cold climates countries or in the region with better adaptability; however, it would be a catastrophe for those who live in hot climates with low adaptation ability.

Furthermore, if the term persecution is used in the context of 'indiscriminate', there will be a gap between the formulation of refugee and the protection they obtain in reality. Refugees from conflicting countries in parts of the Middle East or Africa, for example, flee their countries and cross-national borders due to continuing fears of the existing armed conflict, as well as the psychological damage to their young children who witness violence around them. ${ }^{58}$ In this case, the element of persecution is unclear and unsatisfactory, because the threat that they are actually facing is not on an individual basis. Moreover, the persecution is not on the basis of race, religion, nationality, political opinion, or membership of particular social group as stipulated in the Refugee Convention. In fact, they still get international protection from international humanitarian agencies for indefinite lengths of time.

Persecution should also be seen from the point of view of potential effects. This stand-point defines persecution as encompassing highly likely future circumstance, that will put someone in real danger. In this context, a predictable danger caused by climate change and its related calamities will put someone, or a group of people, in possible hardship.

In mid - 2014 the New Zealand Immigration and Protection Tribunal (hereinafter referred to as NZIPT) granted protection for a Kiribati family. The decision of the Tribunal was based on humanitarian and family considerations, rather than environmental aspects. ${ }^{59}$ The considerations used in this case, for example on the condition of children and family would have been different if the applicant did not have children and was not married; or if the applicant did not have any family members living in the country of destination. Some experts argued that the decision to grant refugee status, in this case, is not going to literally 'open the door' for similar cases

58 For more information, see the 2018 Human Rights Watch Report, 'Middle East Conflicts Spur Disastrous New Trends for Region', (January 2018), https://www.hrw.org/news/2018/01/18/middleeast-conflicts-spur-disastrous-new-trends-region; see also: Phillip Connor, 'Conflicts in Syria, Iraq and Yemen Lead to Millions of Displaced Migrants in the Middle East Since 2005', Pew Research Center, (October 2016), http://www.pewglobal.org/2016/10/18/conflicts-in-syria-iraq-and-yemen-lead-to-millions-of-displaced-migrants-in-the-middle-east-since-2005/; see also: Wesley Dockery, 'Which Conflicts are Causing Migration from Africa?', Info Migrants, (May 2017), http://www.infomigrants.net/en/post/3428/whichconflicts-are-causing-migration-from-africa

59 Library of Congress, 'New Zealand: “Climate Change Refugee” Case Overview', (2015)<https:// www.loc.gov/law/help/climate-change-refugee/new-zealand.php> See: Alex Randall, 'Why New Zealand Did not Accept "World's First Climate 
in the future. ${ }^{60}$ However, it will at least, lay a strong foundation for the acknowledgement of environmental refugees.

However, there are certain situations where environmental matters are closely linked to persecution that fits the definition in the Convention; for example, deliberate actions of the government against any person or group of people affected by environmental disasters, such as government refusal to receive international aid or assistance from other countries in the aftermath of an environmental disaster. Another situation is a deliberate action by the government to poison the water supply, preventing affected people from having adequate access to clean water; or deliberate discrimination against particular persons or a group of people in providing other services during an environmental disaster.

The second point of the Convention definition is that the persecution should be on the grounds of race, religion, nationality, political opinion, or membership of a particular social group. These conditions exclude the potential to form a legal basis for the protection of environmental refugees. The term persecution used in the 1951 Convention is narrowly limited by the conditions following it. None of the conditions (race, religion, nationality, political opinion and membership of social group) provides the possibility for other circumstances to be included, including environmental matters.

However, if persecution is viewed and defined from a different angle, as the cause of an unpleasant situation which triggers displacement, or if the focus is the result of the persecution, in which people are put in danger, climate change and its related calamities can be considered persecution. In the case of a sinking state due to sea level rises, the adverse impacts of climate change could be worse than that of traditional persecution, since environmentally displaced people could lose their citizenship as well as culture, that has been preserved for hundreds of years.

The third element of the Convention is that the affected person has to be outside of their home country. This element seems to be contradictory to what international scholars and organization have suggested: that the adverse effects of climate change will severely affect those who live in developing or poor countries who have less technical and economic ability to deal with the problem. ${ }^{61}$

In practice, the movement of the affected people who are called refugee, to some extent is unclear, whether it is based on the situation of avoiding persecution as

60 See: Alex Randall, 'Why New Zealand Did not Accept “World's First Climate Refugees', Climate Home, (2014), <http://www.climatechangenews.com/2014/08/14/why-new-zealand-did-not-acceptworlds-first-climate-refugees/>; see also: ABC News, 'Tuvalu Climate Family Granted New Zealand Residency on Appeal' (2014), <http://www.abc.net.au/news/2014-08-05/an-tuvalu-climate-family-grantednz-residency-on-appeal/5650584>

61 UNFCCC, 'Climate Change: Impacts, Vulnerabilities and Adaptation in Developing Countries', 2007; <http://unfccc.int/resource/docs/publications/impacts.pdf> 
required in the Convention, or due to other factors. If the reason for the migration is genuinely due to persecution in the home country, one will not migrate to one state for transit, and then move further to another country after a while. Being outside of the home country is adequate to avoid persecution. ${ }^{62}$ One will be safe once He or She arrived in another country. It is no longer His or Her home country's legal jurisdiction. Therefore, when the affected person then decides to move further to another country, the reason for such movement becomes indistinct. Economic reasons to seek a better life seem to be the driving factor, since the threat of persecution no longer exists.

For those who live in developed countries, where the governments are willing and fully capable of looking after their citizens in the aftermath of environmental disasters, cross-border migration will be highly unlikely, compared to internal displacement. Hurricane Katrina, which hit the US in $2005 ;^{63}$ the earthquake that devastated city of Christchurch, New Zealand in 2011;,64 the earth quake in Fukushima, Japan in $2011^{65}$ which resulted in radioactive radiation; Super Typhoon Maysak in the US in 2015; 66 and the floods in Nice and Riviera, France in $2015^{67}$ are only a few examples of environmental calamities that hit certain countries but did not trigger cross-border migration. The willingness of the governments to guarantee the rights of their citizens, supported by advanced security systems, kept the affected people inside their national border, waiting for the conditions to improve.

However, it is not always the same story for people who live in developing countries or poor countries. When natural disasters or environmental changes as a result of climate change swept over the countries, they have to face certain conditions that:

First, they have nothing left with which to continue their life. In most cases, houses, farms, cattle, water resources, and other life-supporting facilities are destroyed; Secondly, the government no longer has the ability to guarantee and protect citizens' rights due to weak economic conditions. Thirdly, when the option to flee their home becomes their last resort, they do not have the ability to cross their national border. In fact, the affected community cannot afford to travel to other

62 If referred to the definition of refugee in the 1951 Refugee Convention.

63 CNN, 'Hurricane Katrina Statistics Fast Facts', (2016) <http://edition.cnn.com/2013/08/23/ us / hurricane-katrina-statistics-fast-facts / >

64 The Sydney Morning Herald, "We May be Witnessing New Zealand's Darkest Day": PM Says 65 Killed in Quake, (2011)<http://www.smh.com.au/world/we-may-be-witnessing-new-zealands-darkestday-pm-says-65-killed-in-quake-20110222-1b356.html>

65 Becky Oskin, ‘Japan Earthquake \& Tsunami of 2011: Facts and Information', (2015), <http:// www.livescience.com/39110-japan-2011-earthquake-tsunami-facts.html>

66 The Weather Channel, 'Super Typhoon Maysak (RECAP)', 2015,<https://weather.com/storms/ typhoon/news/typhoon-maysak-yap-philippines-pacific>

67 BBC News, 'France Floods: 17 Dead on Riviera After Storms' (2015)<http://www.bbc.com/news/ world-europe-34437228> 
countries, due to economic and financial constraints. Therefore, it is important to understand that in most environmentally-induced displacement cases, the affected people tend to stay inside their national border due to lack of economic ability. It is completely different from traditional or political refugee, as they can afford to go to other countries to seek refuge.

The last element of the Convention refugee definition is the inability or unwillingness of the affected people to return to their home countries, due to persecution or potential threats they might face. Continuing fears and trauma in a state of war or conflict, for example, can be a strong legal basis for someone not returning home, especially for women and children, as well as elderly people. However, the nature of this migration is temporary, since they are expected to return to their initial homes when the situation has improved. The situation might be quite similar for migration caused by a rapid-onset disaster, such as earthquake, landslide, flash flood, tsunami or typhoon, where most of the affected people will undergo temporary and internal migration.

However, in slow-onset disasters, such as rising sea levels, salinity, droughts, desertification and land subsidence, people are forced to migrate far before the worst of the disaster actually occurs. In the situation of rising sea levels, for example, people in low-lying states that will potentially be drowned have been forced to make their decision to migrate before the actual inundation occurs. ${ }^{68}$ In this situation, the nature of the migration is permanent, due to unliveable environmental conditions which prevent them returning. Therefore, the implementation of the term 'Unable to return to the initial homes' as a legal basis in claiming international protection can be quite complicated since environmental migrants, to some extent, have to migrate far before the real impact occurs.

While from a legal definition stand-point the term 'environmental refugee' is not legally recognized and regulated in the existing instruments, from a humanitarian point of view, those who are enforced to migrate due to environmental stress have the same rights as traditional refugees. Therefore, decision-makers should implement a broader interpretation and more creative approaches to deal with global humanitarian development problems. This may not be the most appropriate solution to the debate on whether or not environmental migrants should be encompassed in the existing international instrument. However, it can, nevertheless, provide a benchmark for reference and the decision-making process in the future.

\subsection{Environmental Refugees and International Commitment}

It is widely accepted that the term 'environmental refugee' was promulgated and brought to the public debate arena by Essam El Hinnawi, through a promi-

68 See Saiful Huq, Tim Gaynor (ed), UNHCR, 'As Sea Levels Rise, Bangladeshis Seek Higher Ground', (2015) <http://www.unhcr.org/news/latest/2015/12/566ff51f6/sea-levels-rise-bangladeshis-seek-higher-ground.html> 
nent report for the United Nations in $1985 .{ }^{69}$ The term has become a highly debated topic among academics, scholars and international agencies ever since, especially with regard to its controversial legal status and its relation to global environmental problems such as climate change. In brief, the term is used to define people who flee their home countries and cross-national borders due to environmental stress.

However, while the use of the term 'environmental refugees' or 'climate refugees' is intended to provide a strong emphasis on the relationship between climate changes and human migration, ${ }^{70}$ the term 'environmental refugee' is a legal fallacy, ${ }^{71}$ because it is not encompassed in the definition of refugee in the Convention. Therefore, people who flee their countries due to environmental stresses such as droughts, floods, and sea level rises cannot be categorized as refugees.

From moral and humanitarian perspectives, developed countries in which the economic growth rate has far exceeded those of developing countries should have a higher moral awareness to help the affected communities in fighting for their right to obtain a decent and respectable life. As set out in international environmental instruments such as the $\mathrm{UNFCCC}^{72}$ and the Kyoto Protocol, ${ }^{73}$ the obligation to reduce CO 2 emissions is compulsory for developed countries. However, developed countries, due to economic and other considerations, have failed to achieve the goals agreed in the instruments, although international forums have been established to renegotiate the target. ${ }^{74}$

Based on the principle of Common but Differentiated Responsibilities (CBDR), set forth in the Rio Declaration of 1992, both developed and developing countries have similar obligations to reduce the adverse effects of climate change. ${ }^{75}$ The principle requires each state to join the fight against global environmental problems, based on two conditions: firstly, that every state has the same concern regarding climate change as a common problem of human life; secondly, the historical background on the existing global environmental problem and socio-economic conditions of each country in relation to its ability to address the problem. ${ }^{76}$

69 Essam El Hinnawi, Environmental Refugees, UNEP, (1985).

70 Olivia Dun and Francois Gemenne, Op.Cit.

71 Keane, "The Environmental cause and Consequences of Migration: a Search for the Meaning of "Environmental Refugees"', (2004) 16 (209) The Georgetown International Environmental Law Review, 215.

72 the UNFCCC, adopted on 9 May 1992.

73 Kyoto Protocol, adopted on 11 December 1997.

74 See Duncan Clark, "Has the Kyoto Protocol Made any Difference to Carbon Emissions?", the Guardian (November 2012)https://www.theguardian.com/environment/blog/2012/nov/26/kyoto-protocol-carbon-emissions

75 As explicitly stated on article 3 (1) and 4 (1) of the United Nations Framework Convention on Climate Change.

76 CISDL, 'The Principle of Common but Differentiated Responsibilities: Origins and Scope', (2002); <http://cisdl.org/public/docs/news/brief_common.pdf> 
Under the principle of CBDR, ${ }^{77}$ all countries have the same responsibility to the existing global environmental problems. Similar provisions are also seen in the 1992 UNFCCC:

... on the basis of equity and in Accordance with Reviews their common but differentiated responsibilities and respective capabilities.

Furthermore, the UNFCCC also states that the impact of climate change on the rest of humanity is a "common concern of Humankind", ${ }^{78}$ which can be interpreted as an order to every state, without exception, to join the fight against climate change.

This principle regulates not only the legal responsibility for developed countries to take appropriate and foremost efforts to address this global issue, but also implies a moral duty to assist less developed countries to escape from the misfortune. This moral responsibility has played a vital role in determining the problems, given that international instruments seem to be less likely to enforce robust and specific sanctions, in terms of penalties and punishment for countries that do not meet their obligations. When a country does not want to be bound by being a party to an international instrument, international law cannot force it to be on board. ${ }^{79}$

Moreover, there is no legal obligation for the states as parties of the Refugee Convention to recognize and to render protection for the affected people, ${ }^{80}$ and the question remains as to whether it is possible for millions of migrants to rely on the commitment and willingness of developed countries. Given this, who should be responsible for this kind of migration? Do the responsibilities really exist based on international legal instruments? Looking at the previous experiences on the implementation of the UNFCCC and the Kyoto Protocol, the answer seems to be 'no'. ${ }^{81}$

The developed countries' reluctance and refusal of the concept of environmental/ climate refugees seem to be based on the premise that accepting the concept will implicitly confirm that the current climate problem is due to their contributions, and that therefore they should be fully responsible for addressing the problem. ${ }^{82}$ Regardless of whether or not the environmental refugee is recognized, developed countries should accept that scientific evidence has demonstrated the close relationship between climate change and industrialization or the use of fossil fuels. IPCC as an acknowledged international scientific body has provided robust evidence on this matter.

77 Can be seen in Principle 7 of the Rio Declaration.

78 As clearly acknowledged in the preamble of the Convention.

79 Jack L. Goldsmith and Eric Posner, The Limits of International Law (New York: Oxford University Press, 2005).

80 Elizabeth Mc Namara, 'Conceptualizing Discourses on Environmental Refugees at the United Nations,' Population and Environment 29, no. 1 (2007): 12.

81 Angela Williams, Op.Cit, 516-518.

82 Ibid. 
In relation to human displacement, the fact that most of the world's refugee population, which has reached 10 million, are accommodated in developing countries has shown that developed countries have the less political will to address this global humanitarian problem. ${ }^{83}$ Success in solving the problems of human displacement in relation to climate change will come from all countries, especially developed countries, assisting the affected people to strive to ameliorate their condition and to regain their basic rights, such as the rights to life, adequate food, clean drinking water, proper education for their children, adequate housing and the best attainable health service. UNEP in its report has asserted that without a vigorous commitment from industrial countries to implement a policy to significantly reduce $\mathrm{CO} 2$ emissions released into the atmosphere, within the next decade the problem of climate change and its adverse impacts will worsen. ${ }^{84}$

It is argued here that there are several reasons why environmental migrants should get the same protection and treatment as other traditional refugees: First, the rights of the affected people have been stipulated in international human rights documents such as the Universal Declaration of Human Rights (UDHR) and the 1966 International Covenant on Economic, Social and Cultural Rights (ICESCR), including the right to life, adequate food, clean water, adequate shelter, health and education. The right to a decent life as a human being is also set in the 1972 Stockholm Declaration on the Human Environment, which states:

"Man has the fundamental rights to freedom, equality and adequate conditions of life, in an environment of a quality that permits a life of dignity and well-being"

Secondly, environmental migrants are the victims of human activities, which have caused severe distress. These people have been involuntarily forced to flee their homes in order to find a better place to live. Thirdly, states cannot keep 'burying their head in the sand' and ignoring environmental refugees simply because there is no accepted international legal agreement or common institutionalized instrument. In fact, the numbers of people affected by environmental distress are increasing, and the adverse impacts of climate change are predicted to be worse in the future. Fourthly, a widely accepted international instrument (UNFCCC) states that the adverse effects of climate change are a common concern of humankind, and therefore urges every country to address this issue, and, in particular, for developed countries to take the lead in assisting developing countries to cope with this problem.

83 UNEP, 'Human Development Report 2007/2008: Fighting Climate Change: Human Solidarity in a Divided World', (2007),8. <http://hdr.undp.org/sites/default/files/reports/268/hdr_20072008_en_complete.pdf; $>$ Watch also a talk with Dr. Jeff Crisp, 2011 Refugee Conference - Prof Jane Mc Adam in conversation with Dr Jeff Crisp, UNSWTV, (2011);

<https: / / www.youtube.com/watch?v=xLGbVgSTXx0\&index=3\&list=FLiuo-BT1POFP132ee0SIYwQ>

84 UNEP, 'The Emissions Gap Report, 2014, A UNEP Synthesis Report'; <http://www.unep.org/ publications/ebooks/emissionsgapreport2014/portals/50268/pdf/EGR2014_LOWRES.pdf;see also: IPCC, Climate Change 2007: synthesis report, (2007); <https://www.ipcc.ch/pdf/assessment-report/ar4/ syr/ar4_syr.pdf> 


\section{Conclusion and Recommendation}

Some have argued that a specific instrument for regulating environmental refugees will not improve the situation on the grounds that, firstly, most of the movements undertaken by the affected people are internal (within their national territories), and secondly, that it will be highly dependent on the political will of governments to acknowledge them.

Notwithstanding this, international instruments are important to safeguard the protection of the affected communities from adverse environmental changes and to allow them to maintain a subsistent standard of living. This will ensure that crossborder migration resulting from the environmental catastrophe will not take place in a legal vacuum, and such refugees maintain their fundamental legal rights.

There is a very limited number of scholarly articles that present solid argument on narrow interpretation of refugee in the Refugee Convention. Therefore, further research is needed on the implementation of the convention and how the convention will affect decision-makers in dealing with humanitarian problems.

As climate change has been closely associated with human activities, specifically, industrialization and the use of fossil fuels, developed or industrialized countries bear a moral and historical responsibility to prevent violations of the fundamental rights set forth in international documents due to climate change. The fact that climate change has played an important role in triggering human displacement, even though it is not entirely the root cause of the migration, means that countries cannot be careless about the fate of the affected community. Similarly, it means that environmental migrants deserve protection, and global efforts to acknowledge them.

Developed or industrialized countries should have a moral and historical responsibility as contributing parties to greenhouse gases. The principle of Common but Differentiated Responsibility, which has been regarded as customary international law, clearly imposes a duty on every state to take on their respective roles in the fight against climate change in accordance with their capacity and capability. This principle should also be seen as putting the same responsibility on each state when the adverse impacts of climate change started affecting other countries, especially countries that contribute the least greenhouse gases.

Another principle, that is important in determining the responsibility of a state for the impacts of climate change is the 'No harm rule', which is basically a set of obligations not to cause damage or harm to other countries as a result of activities undertaken. This principle is closely related to the principle of 'State Responsibility', which has been widely accepted as a norm of international law. 
Regardless of the highly debatable definition of 'refugee' and the fact that environmental refugees are not in line with the international legal framework, an international instrument on the status of those who migrate as a result of environmental stress will be necessary and useful as a preventive measure when such event occurs. However, such an arrangement will be greatly influenced by the commitment and willingness of governments, particularly those of developed countries, which will play a vital role in solving the problem.

In fact, while developing countries have contributed the least to the climate changes crisis, if developed or industrialized countries releasing greenhouse gases such as carbon dioxide into the atmosphere at the current pace, developing countries will suffer the most from the crisis. This means that more environmental migrants will be created every year. What is the difference if, in the end, the UNHCR asks countries to assist people displaced by climate change? Instead, the problem can be made straightforward by acknowledging the status of the people as refugees under an international legal document.

\section{Acknowledgement}

I would like to thank my former PhD Supervisors, Professor Ben Boer and Professor Tim Stephens, from the University of Sydney for their highly valuable comments and support in the completion of this article. The views expressed herein are those of the author and do not necessarily attributed and represent the views of the institution for which He is affiliated with. 


\section{BIBLIOGRAPHY}

\section{Book}

Birne, Patricia, Alan Boyle, Catherine Ridgwell. International Law and the Environment. New York: Oxford University Press, 2009.

Goldsmith, Jack L., and Eric A. Posner. The Limits of International Law. New York: Oxford University Press, 2005.

Kolmansskog, Vikram Odedra. Future Floods of Refugees: A Comment on Climate Change, Conflict and Forced Migration. Oslo: Norwegian Refugee Council, 2008.

McAdam, Jane. Climate Change, Forced Migration, and International Law. New York: Oxford University Press, 2012. DOI:10.1093/acprof:oso/9780199587087.001 .0001

\section{Book Review}

Baldwin, Andrew. "Rising Tides: Climate Refugees in the Twenty-first Century," by John Wennersten and Denise Robbins, book review, International Migration Review 1-3, 2018. 2018, https://doi.org/10.1177/0197918318770161.

\section{Journal Article}

Ahmad, Bayes. "Who Takes Responsibility for the Climate Refugees?," International Journal of Climate Change Strategies and Management 10, no. 1 (2018): 5-26. https://doi.org/10.1108/IJCCSM-10-2016-0149

Bates, Diane C. "Environmental Refugees? Classifying Human Migrations Caused by Environmental Change." Population and Environment 23, no. 5 (2002): 465-477

Biermann, Frank, and Ingrid Boas. "Preparing for a Warmer World: Towards a Global Governance System to Protect Climate Refugees." Global Environmental Politics 10, no. 1 (2010): 60-88. https://doi.org/10.1162/glep.2010.10.1.60

Boer, Ben and Alan Boyle. "Human Rights and the Environment." Background Paper for the 13th Informal ASEM Seminar on Human Rights, Sydney Law School Research Paper, no. 14/14. (2014): 1-88. http://dx.doi.org/10.2139/ ssrn.2393753 
Bozdag, Cigdem, and Kevin Smets. "Understanding the Images of Alan Kurdi With "Small Data": A Qualitative, Comparative Analysis of Tweets About Refugees in Turkey and Flanders (Belgium)." International Journal of Communication 11 (2017): 4046-4069.

Brzoska, Michael and Christiane Fröhlich. "Climate Change, Migration and Violent Conflict: Vulnerabilities, Pathways and Adaptation Strategies." Migration and Development 5, no.2 (2016): 190-210. https://doi.org/10.1080/21632324.20 15.1022973

Burleson, Elizabeth. 'Climate Change Displacement to Refuge.' Journal of Environmental Law and Litigation 25, no. 19 (2010): 19-36.

Docherty, Bonnie, and Tyler Giannini. "Confronting a Rising Tide: A Proposal for a Convention on Climate Change Refugees." Harvard Environmental Law Review 33 (2009): 349-403.

Greussing, Esther, and Hajo G. Boomgaarden. "Shifting the Refugee Narrative? An Automated Frame Analysis of Europe's 2015 Refugee Crisis.” Journal of Ethnic and Migration Studies 43, no. 11 (2017): 1749-1774. https://doi.org/10.1080/ 1369183X.2017.1282813

Hansen, Randall. "The Comprehensive Refugee Response Framework: A Commentary." Journal of Refugee Studies 31, no. 2 (2018): 131-151. https://doi.org/10.1093/ jrs / fey020

Hendrix, Cullen S. and Idean Salehyan. "Climate Change, Rainfall, and Social Conflict in Africa." Journal of Peace Research 49, no. 1 (2012): 35-50. https://doi. org/10.1177/0022343311426165

Hingley, Rebecca. "Climate Refugees: An Oceanic Perspective." Asia and the Pacific Policy Studies 4, no. 1 (2017):158-165.

Keane, David. "The Environmental Causes and Consequences of Migration: A Search for the Meaning of Environmental Refugees." Georgetown International Environmental Law Review 16 (2004): 209-223.

Kibreab, Gaim. "Environmental Causes and Impact of Refugee Movements: A Critique of the Current Debate.” Disasters 21, no. 1 (1997): 20-38. https:// doi.org/10.1111/1467-7717.00042

Kolmannskog, Vikram, and Lisetta Trebbi. "Climate Change, Natural Disasters and Displacement: A Multi-Track Approach to Filling the Protection Gaps." International Review of the Red Cross 92, no. 879 (2010): 713-730. https:/ doi. org/10.1017/S1816383110000500 
Lonergan, Steve. "The Role of Environmental Degradation in Population Displacement." Environmental Change And Security Project Report 4, no. 6 (1998): 5-15.

McAdam, Jane. "Swimming against the Tide: Why a Climate Change Displacement Treaty is not the Answer." International Journal of Refugee Law 23, no. 1 (2011): 2-27. https://doi.org/10.1093/ijrl/eeq045

McNamara, Karen Elizabeth. "Conceptualizing Discourses on Environmental Refugees at the United Nations." Population and Environment 29, no. 1 (2007): 12-24. https:/ / doi.org/10.1007/s11111-007-0058-1

Myers, Norman. "Environmental Refugees in a Globally Warmed World." Bio Science 43, no. 11 (1993): 752-761. DOI: 10.2307/1312319

Myers, Norman. 'Environmental Refugees," Population and Environment 19, no.2 (1997): 167-182. https://doi.org/10.1023/A:1024623431924

Selby, Jan, and Clemens Hoffmann. "Beyond Scarcity: Rethinking Water, Climate Change and Conflict in the Sudans." Global Environmental Change 29 (2014): 360-370. https://doi.org/10.1016/j.gloenvcha.2014.01.008

Stevens, Dallal. "Asylum, Refugee Protection and the European Response to Syrian Migration.” Journal of Human Rights Practice 9, no. 2 (2017): 184-189. https:// doi.org/10.1093/jhuman/hux016

Williams, Angela. "Turning the Tide: Recognizing Climate Change Refugees In International Law." Law \& Policy 30, no. 4 (2008): 502-529. https: / / doi.org/10.1111/ j.1467-9930.2008.00290.x

Worster, William Thomas. "The Evolving Definition of the Refugee in Contemporary International Law." Berkeley Journal of International Law 30 (2012): 94-160. http:/ /dx.doi.org/https://doi.org/10.15779/Z38ZP90

\section{Legal Documents}

\section{International Instruments}

African Union Convention

The 1951 Convention relating to the status of Refugee

Kyoto Protocol

Rio Declaration on Environment and Development 
The Global Compact on Refugees, $3^{\text {rd }}$ Draft (as at 26 June 2018)

United Nations Framework Convention on Climate Change

United Nations General Assembly, A/RES/71/1 (2016)

Draft Convention on the International Status of Environmentally-Displaced Persons, (2013)

\section{Other Documents/Reports}

Chase Sova. "The First Climate Change Conflict", World Food Program USA (November 2017) https://wfpusa.org/articles/the-first-climate-change-conflict/

IPCC, 'Climate Change 2007: Impacts, Adaptation and Vulnerability' (2007)<https:/ / www.ipcc.ch/pdf/assessment-report/ar4/wg2/ar4_wg2_full_report.pdf>

IPCC, 'Climate Change 2014: Synthesis Report', (2015), <http://www.ipcc.ch/pdf/ assessment-report/ar5/syr/SYR_AR5_FINAL_full.pdf

The 2018 Human Rights Watch Report, 'Middle East Conflicts Spur Disastrous New Trends for Region', (January 2018), https://www.hrw.org/news/2018/01/18/ middle-east-conflicts-spur-disastrous-new-trends-region UNEP, 'Human Development Report 2007/2008: Fighting Climate Change: Human Solidarity in a Divided World', (2007),<http://hdr.undp.org/sites/default/files/reports/268/ hdr_20072008_en_complete.pdf;>

Phillip Connor, 'Conflicts in Syria, Iraq and Yemen Lead to Millions of Displaced Migrants in the Middle East Since 2005', Pew Research Center, (October 2016), http:/ / www.pewglobal.org/2016/10/18/conflicts-in-syria-iraq-and-yemenlead-to-millions-of-displaced-migrants-in-the-middle-east-since-2005/;

UNEP, The Emissions Gap Report, 2014, A UNEP Synthesis Report'; <http://www. unep.org/publications/ebooks/emissionsgapreport2014/portals/50268/pdf/ EGR2014_LOWRES.pdf;see also: IPCC, Climate Change 2007: synthesis report, (2007); <https://www.ipcc.ch/pdf/assessment-report/ar4/syr/ar4_syr.pdf>

UNHCR, '2007 Global trends: Refugees, Asylum Seekers, Returnees, Internally Displaced and Stateless Persons' (2008) <http://www.unhcr.org/4852366f2. html>

Wesley Dockery, 'Which Conflicts are Causing Migration from Africa?', Info Migrants, (May 2017) 
World Food Program USA Report, "Winning the Peace: Hunger and Instability" (December 2017)

\section{News or Magazine Article}

Ineli-Ciger, Meltem. "Will the Global Compact on Refugees Address the Gap in International Refugee Law Concerning Burden Sharing?," European Journal of International Law (EJIL) Talk!, June 20, 2018, https://www.ejiltalk.org/willthe-global-compact-on-refugees-address-the-gap-in-international-refugee-lawconcerning-burden-sharing/

Poon, Jenny. "Addressing the Protection Gap of Environmental Refugees: A Reform of the 1951 Refugee Convention?," Groningen Journal of International Law, blog, March 28, 2017, https://grojil.org/2017/03/28/addressing-the-protectiongap-of-environmental-refugees-a-reform-of-the-1951-refugee-convention/

\section{Website Content}

ABC News, 'Tuvalu Climate Family Granted New Zealand Residency on Appeal' (2014), <http://www.abc.net.au/news/2014-08-05/an-tuvalu-climate-familygranted-nz-residency-on-appeal/5650584>

Al Jazeera, 'Inside Story: Is Climate Change A Global Security Threat?', Video, (2011);<https://www.youtube.com/watch?v=7KsegrvRWZQ>

Alberto Angulo Morales, Oscar Alvarez Gila, 'Disasters and Migration in Western Early Modern Societies (17th-18th Centuries)', (2014) Migracionesen 3

Milenio.indd<http://www.academia.edu/6717913/Disasters_and_Migration_in_ Western_Early_Modern_Societies_17th-18th_Centuries

Alex Randall, 'Why New Zealand Did not Accept "World's First Climate Refugees', Climate Home, (2014),<http://www.climatechangenews.com/2014/08/14/ why-new-zealand-did-not-accept-worlds-first-climate-refugees / >;

Antonio Guterres, 'Climate change, natural disasters and human displacement: a UNHCR perspective', (2008) <http://www.unhcr.org/4901e81a4.pdf>

BBC News, 'France Floods: 17 Dead on Riviera After Storms', (2015)<http://www. bbc.com/news/world-europe-34437228>

Becky Oskin, 'Japan Earthquake \& Tsunami of 2011: Facts and Information', (2015), <http:/ /www.livescience.com/39110-japan-2011-earthquake-tsunami-facts. html> 
Carolina Fritz, 'Climate Change and Migration: Sorting Through Complex Issues Without the Hype', (2010)<http://www.migrationpolicy.org/article/climatechange-and-migration-sorting-through-complex-issues-without-hype

CISDL, "The Principle of Common but Differentiated Responsibilities: Origins and Scope', (2002); <http:/ / cisdl.org/public/docs/news/brief_common.pdf>

CNN, 'Hurricane Katrina Statistics Fast Facts', (2016), <http://edition.cnn. com/2013/08/23/us/hurricane-katrina-statistics-fast-facts / >

Jeff Crisp, 2011 Refugee Conference - Jane Mc Adam in conversation with Jeff Crisp, UNSWTV, (2011); <https://www.youtube.com/watch?v=xLGbVgSTXx0\&index =3\&list=FLiuo-BT1POFP132ee0SIYwQ>

Olivia Dun and Francois Gemenne, "Defining 'Environmental Migration," Forced Migration Review 31 (2008): 10-11. http://ro.uow.edu.au/cgi/viewcontent.cgi?ar ticle $=2406 \&$ context $=$ sspapers

Essam El Hinnawi, Environmental Refugees, UNEP, (1985)

Freija Van Duijne, 'Scientists's Prediction of Climate Change: Business as Usual Versus Alternative Futures', (2015);<http://futuristablog.com/scientists-prediction-climate-change-business-usual-versus-alternative-futures / >

Immigration and Protection Tribunal New Zealand, "[2014] NZIPT 800517520<https: / / forms.justice.govt.nz/search/IPT/Documents / Deportation/pdf/ rem_20140604_501370.pdf

International Organization for Migration, 'Migration, Environment and Climate Change: Assesing the Evidence', (2009)<http://publications.iom.int/system/ files/pdf/migration_and_environment.pdf>

IOM, 'Migration, Climate Change and the Environment', <https://www.iom.int/ $\mathrm{cms} / \mathrm{en} / \mathrm{sites} /$ iom/home/what-we-do/migration-and-climate-change/definitional-issues.html>

Library of Congress, 'New Zealand: "Climate Change Refugee" Case Overview', $(2015)<$ https://www.loc.gov/law/help/climate-change-refugee/new-zealand.php>

N95/09386 [1996] RRTA 3191 (7 November 1996); 0907346 [2009] RRTA 1168 (10 December 2009); 1004726 [2010] RRTA 845 (30 September 2010).

Norman Myers, "Environmental Refugees: An Emergent Security Issue", A paper presented at the Economic Forum (May 2005)https://www.osce.org/ eea/14851?download=true 
Richard Black, 'Environmental Refugees: Myth or Reality?', (2001); http://www.unhcr.org/3ae6a0d00.html

Saiful Huq, Tim Gaynor (ed), UNHCR, 'As Sea Levels Rise, Bangladeshis Seek Higher Ground', (2015)<http:/ /www.unhcr.org/news/latest/2015/12/566ff51f6/sealevels-rise-bangladeshis-seek-higher-ground.html>

The Sydney Morning Herald, "We May be Witnessing New Zealand's Darkest Day": PM Says 65 Killed in Quake, (2011),<http://www.smh.com.au/world/we-may-bewitnessing-new-zealands-darkest-day-pm-says-65-killed-in-quake-201102221b356.html>

The Telegraph, 'Kiribati Climate Change Refugee Rejected by New Zealand', (2013);<http:/ /www.telegraph.co.uk/news/worldnews/australiaandthepacific/kiribati / 10474602 / Kiribati-climate-change-refugee-rejected-by-New-Zealand.html>

The Weather Channel, 'Super Typhoon Maysak (RECAP)', 2015,<https://weather. com/storms/typhoon/news/typhoon-maysak-yap-philippines-pacific>

UNFCCC, 'Climate Change: Impacts, Vulnerabilities and Adaptation in Developing Countries', 2007;<http://unfccc.int/resource/docs/publications/impacts.pdf>

UNHCR, 'Climate Change, Natural Disaster, and Human Displacement: a UNHCR Perspective', (2009), 3<http://www.unhcr.org/4901e81a4.html>

UNHCR, 'UNHCR Backs Increased Protection for People Fleeing Disasters and Climate Change' (2015)<http:/ /www.unhcr.org/news/latest/2015/10/561e77f56/unhcr-backs-increased-protection-people-fleeing-disasters-climate-change.html>

UNHCR, 'UNHCR Pledges to Better Protect and Assist People Displaced by Disaster',(2016)<http: / /www.unhcr.org/news/latest/2016/5/574843f34/unhcr-pledges-better-protect-assist-people-displaced-disaster.html>

United Nations University, As Ranks of “Environmental Refugees” Swell Worldwide, Calls Grow for Better Definition, Recognition, Support, (October 2005);<http:// www.ehs.unu.edu/file/get/3916>

Walter Kalin, 'The Climate Change-Displacement Nexus', (Brookings, 2008); <http:/ / www.brookings.edu/research/speeches/2008/07/16-climate-change-kalin> 